\title{
RESPONSE OF THREE SWEET SORGHUM VARIETIES TO POTASSIUM MINERAL - AND BIO - FERTILIZATION
}

\author{
EL-SHEIKH, S.R.E., A.H.S.A. EL-LABBODY AND A.M.H. OSMAN
}

Sugar Crops Research Institute, ARC, Giza, Egypt

(Manuscript received 28 March 2011)

\begin{abstract}
Two field trials were conducted during the summer seasons of 2009 and 2010 on sweet sorghum at Giza Agricultural Research Station. Agricultural Research Center, Giza Governorate, to study the effect of three treatments of potassium fertilization, viz., 24 and $30 \mathrm{~kg} \mathrm{~K} 2 \mathrm{O} / \mathrm{fed}$ as potassium sulfate $48 \% \mathrm{~K}_{2} \mathrm{O}$ as a mineral fertilizer, both of them with 2 bags bio-fertilizer (potassium Mag/fed as a recommended dose) and $36 \mathrm{~kg} \mathrm{~K} \mathrm{~K}_{2} \mathrm{O} / \mathrm{fed}$ without bio-fertilizer on yield/fed and chemical composition of three sweet sorghum varieties, namely, Honey, Brandes and Sorgo. Sweet sorghum varieties differed significantly for stripped stalk, juice and surup yields/fed, TSS, purity and extracted juice $\%$ as well as chemical composition, i.e. sucrose $\%$ and reducing sugars $\%$ in juice and syrup. Sorgo variety was the best as compared to Brandes and Honey. The highest values of the most aforementioned traits were obtained at $30 \mathrm{~kg} \mathrm{~K} \mathrm{O} / \mathrm{fed}$ with 2 bags of biofertilizer. The interaction between all studied traits were insignificantly affected in both seasons. Therefore, these results give evidence to the use of sweet sorghum for syrup production instead of sugar cane, to reduce the vast gab between sugar production and consumption.
\end{abstract}

Key words: Sweet sorghum, potassium, biofertilization, syrup and TSS\%.

\section{INTRODUCTION}

Sweet sorghum is cultivated mainly for its syrup, which is called Black honey. It is predicted to be one of the major sources for syrup production in the near future if the sorghum syrup quality improved. Good sorghum syrup is light colored and mild and has a characteristic of flavor. (Osman et. al. 2005 and Mohamed et. al. 2006). Therefore this leads to save cane yield for sugar production and reduce the vast gab between sugar production and consumption which reached about 1.10 million ton. It is still imported annually (CCSC 2010). Sweet sorghum productivity and quality are affected greatly by many factors. Variety selection is one of the most important decisions in the production of sweet sorghum syrup. There is a great variation among sorghum varieties in stalk height, diameter, number of internodes, syrup production and yield and its components (Miller and Creelman 1982 and Chawdhury and Rahman 1990 and Mohamed et. al. 2006). In this respect, Nour El Hoda et. al. (1994) and Mohamed et. al. (2006) illustrated that stripped stalk yield, was the effective 
parameter on juice and syrup yield, in addition to the chemical characteristics which in turn affect syrup quality of sweet sorghum varieties. Ismail et. al. (2007) and Aly et. al. (2008) reported that sweet sorghum varieties show significant differences in leaf area, leaf area index, plant height and diameter, TSS\%, sucrose $\%$, purity\%, juice and syrup extraction\%, stripped stalk, juice and syrup yields.

Potassium is known for its role in sucrose translocation and accumulation in storage tissues of plants. In this respect, potassium fertilizer increases the sucrose \% without significant reduction in purity\%. potassium fertilizer for sweet sorghum supply 40 pounds for each unit of $\mathrm{K}_{2} \mathrm{O} /$ acre is essential to get high yields. A five to seven tons/acre sorghum crop will remove about $180 \mathrm{lb} \mathrm{K} \mathrm{K}_{2} \mathrm{O} / \mathrm{acre}$ (Undersander et. al. 1990). El-Zeny (2004) found that juice extraction\%, juice yield, syrup extraction\%, syrup yield, total soluble solids, sucrose $\%$ were significantly increased by applying potassium fertilizer at $30 \mathrm{~kg} \mathrm{~K} 2 \mathrm{O} / \mathrm{fed}$. Mohamed et. al. (2006) found that maximum stripped stalk and syrup yield of sweet sorghum were obtained using potassium fertilization at the rate of $24 \mathrm{~kg} \mathrm{~K}{ }_{2} \mathrm{O} /$ fed for both varieties. Meantime, such treatment enhanced greatly juice and syrup quality. This work was carried out to obtain the highest yield and quality of some sweet sorghum varieties by applying different doses of potassium mineral fertilizer and biofertilizer.

\section{MATERIALS AND METHODS}

Two field trials were conducted during the summer seasons of 2009 and 2010 on sweet sorghum (Sorghum bicolor L. Moench) at Giza Agricultural Research Station. Agrucltural Research Center, (Giza Governorate), to study the effect of three levels of potassium fertilizer ( 24 and $30 \mathrm{~kg} \mathrm{~K} \mathrm{~K}_{2} \mathrm{O} /$ fed potassium sulfate as a mineral fertilizer both of them with 2 bags of biofertilizer potassium Mag/fed as a recommended dose) and $36 \mathrm{~kg} \mathrm{~K} \mathrm{~K}_{2} \mathrm{O} / \mathrm{fed}$ without biofertilizer on yields/fed and chemical compositions of three sweet sorghum varieties, viz., Honey, Brandes and Sorgo. A split plot design with four replications was used, potassium and biofertilizer levels i.e., the three levels of potassium fertilizer were allocated to the main plots and the three sorghum varieties to the sub plots. Plot size was $14 \mathrm{~m}^{2}$ (1/300 fed) and consisted of four rows, $7 \mathrm{~m}$ long and $50 \mathrm{~cm}$ apart. Sowing date was $1^{\text {st }}$ of May and harvest was done after four months from sowing in both seasons. Seeds were inoculated before sowing with potassium Mag (recommended dose 2 bags/fed) in a shadow place pre planting and immediately sown and irrigated. The biofertilizer was provided by the Biofertilization Unit, Soil, Water and Environment Research Institute, Agricultural Research Center. Nitrogen fertilizer (as urea $46.5 \% \mathrm{~N}$ ), was added at the recommended rate of $60 \mathrm{~kg}$ 
$\mathrm{N} /$ fed in two equals doses, the $1^{\text {st }}$ one was after one month from sowing and the $2^{\text {nd }}$ one 15 days later. Phosphorus fertilizer (as calcium superphosphate $15.5 \% \mathrm{P}_{2} \mathrm{O}_{5}$ ), was added at the recommended rate of $15 \mathrm{~kg} /$ fed during seed bed preparation. Potassium fertilizer (as potassium sulphate $48 \% \mathrm{~K}_{2} \mathrm{O}$ ), was added at the 24 , 30 with biofertilizer and $36 \mathrm{~kg} \mathrm{~K} 2 \mathrm{O} / \mathrm{fed}$ without biofertilizer in two equal doses with nitrogen fertilizer. All Agricultural practices were done as recommended by Sugar Crops Research Institute. Some physical and chemical properties of the experimental soils were analyzed according to Jakson (1967) and shown in Table (1).

Table 1. Some physical and chemical analyses of the experimental soils*.

\begin{tabular}{|c|c|c|c|c|c|c|c|c|c|c|c|}
\hline \multicolumn{5}{|c|}{ Particle size \% } & $\begin{array}{l}\text { oil } \\
\text { ture }\end{array}$ & \multirow{2}{*}{\multicolumn{2}{|c|}{$\begin{array}{l}* * \text { E.C. } \\
\text { ds/m }\end{array}$}} & \multirow{2}{*}{$\begin{array}{c}\text { Soil } \\
\mathrm{pH}^{* * *}\end{array}$} & \multirow{2}{*}{\multicolumn{2}{|c|}{$\begin{array}{c}\text { Organic matter } \\
\qquad \%\end{array}$}} & \multirow{2}{*}{$\begin{array}{c}\mathrm{CaCO} 3 \\
\%\end{array}$} \\
\hline Sand & Silt & Clay & \multicolumn{2}{|c|}{ Fine sand } & \multirow{2}{*}{ lay } & & & & & & \\
\hline 11.20 & 25.70 & 60.10 & & & & & & 8.00 & & & 1.60 \\
\hline \multicolumn{4}{|c|}{ Soluble Cations (meq/L) } & \multicolumn{5}{|c|}{ Soluble anions(meq/L) } & \multicolumn{3}{|c|}{$\begin{array}{l}\text { Total available contents } \\
\text { (ppm) }\end{array}$} \\
\hline $\mathrm{Ca}^{++}$ & $\mathrm{Mg}^{++}$ & $\mathrm{Na}^{+}$ & $\mathrm{K}^{+}$ & $\mathrm{CO}^{--}$ & & & $\mathrm{Cl}^{-}$ & $\mathrm{SO}^{--}$ & $\mathrm{N}$ & $P$ & $\mathrm{~K}$ \\
\hline 5.10 & 2.60 & 16.30 & 0.35 & 0.10 & & & 9.40 & 13.30 & 36.0 & 6.91 & 280.51 \\
\hline
\end{tabular}

* Each value represents the average of 4 samples at both seasons.

** EC = Electrical conductivity was measured in a soil - water extract (1:5).

$* * * \mathrm{pH}$ was measured in a soil - water suspension (1: 2.5).

\section{Recorded data}

At the dough stage (content of seeds are firm and easily crushed between thumb and index fingers), the plants were harvested after 120 days from sowing. A sample of twenty stalks from each subplot was taken at random to determine the following parameters:

\section{- Yield and extracted juice}

- Yield and juice extracted were determined from plants taken from the two middle rows of each sub plot to avoid the border effect. Sample size of 10 plants/plot was used to determine stripped stalk, juice and syrup (tons/fed) according to AOAC (2005).

\section{- Extraction juice \%}

- Brix\% was determined by Brix hydrometer standardized at $20^{\circ} \mathrm{C}$.

- Purity $\%$ was determined by the following equation:

Purity $\%=$ Sucrose $\% \times 100 /$ TSS $\%$.

- Juice and syrup extraction (JSE)\% was estimated from the following formula:

JSE $\%=$ juice or syrup yield ton/fed $\times 100 /$ stripped stalk yield ton/fed. 


\section{- Chemical composition}

- Extraction juice and syrup\% were chemically analyzed for sucrose $\%$, reducing sugars\% which were determined according to methods described by AOAC (2005). Als, $\mathrm{pH}$ value was measured by a Beckman $\mathrm{pH}$ meter according to Collins et. al. (1987).

Data were statistically analysed at $5 \%$ level of probability according to Snedecor and Cochran (1981).

\section{RESULTS AND DISCUSSION}

\section{Varietal effects}

\section{-Yields and extracted juice}

The results obtained in Table (2) revealed that varieties significantly differed in stripped stalks, juice and syrup yields/fed in both seasons. The highest values of studied traits were recorded by variety Sorgo as compared with the other varieties, i.e. Brandes and Honey. The differences in these traits among genotypes might be due to the differences in their genetic the make-up. (Nour El Hoda et. al. 1994 and Mohamed et. al. 2006).

Table 2. Effect of varieties on yield/fed and extracted juice \%.

\begin{tabular}{|c|c|c|c|c|c|c|}
\hline \multicolumn{7}{|c|}{2009 season } \\
\hline Sweet & \multicolumn{3}{|c|}{ Yields (ton/fed) } & \multicolumn{3}{|c|}{ Extracted juice } \\
\hline Varieties & $\begin{array}{c}\text { Stripped } \\
\text { stalk }\end{array}$ & Juice & Syrup & $\begin{array}{c}\text { Total soluble } \\
\text { solids } \% \\
\end{array}$ & Purity\% & $\begin{array}{c}\text { Juice } \\
\text { extraction\% }\end{array}$ \\
\hline Honey & 28.25 & 12.89 & 1.45 & 20.41 & 53.41 & 45.63 \\
\hline Brandes & 29.31 & 13.94 & 2.59 & 19.94 & 58.98 & 47.56 \\
\hline Sorgo & 30.33 & 14.92 & 2.89 & 18.17 & 67.86 & 49.19 \\
\hline LSD 5\% & 1.45 & 0.54 & 0.19 & 1.10 & 4.78 & 1.29 \\
\hline \multicolumn{7}{|c|}{2010 season } \\
\hline Honey & 29.12 & 13.74 & 1.59 & 21.65 & 51.04 & 47.18 \\
\hline Brandes & 30.22 & 14.44 & 2.12 & 20.11 & 63.80 & 47.78 \\
\hline Sorgo & 31.39 & 15.59 & 2.86 & 19.38 & 69.35 & 49.67 \\
\hline LSD 5\% & 0.84 & 0.17 & 0.15 & 0.75 & 4.25 & 0.93 \\
\hline
\end{tabular}

\section{- Extracted juice}

The results in Table (2) indicated that TSS, purity\% and extraction juice\% traits significantly differed between the three varieties in both seasons. Variety Honey 
produced the highest values of TSS\% of juice. While, variety Sorgo had the highest purity and extraction juice\% compared to the other varieties. This result might be mainly due to the fact that the non sugar substances $\%$ of juice and fiber content were lower for Honey variety than Brandes and Sorgo. Similar findings were obtained by Nour El Hoda et. al. (1994) and Mohamed et. al. (2006).

\section{- Chemical composition}

Results in Table (3) showed that sweet sorghum varieties differed significantly in chemical composition in both seasons. The obtained results in Table (3) indicate that sucrose $\%$ and reducing sugars $\%$ in extracted juice and syrup as well as extracted syrup $\%$ were significantly affected by sweet sorghum varieties, while, $\mathrm{pH}$ values did not differ significantly in both seasons. It is important to mention that Sorgo was the best variety where, it gave the highest value of sucrose $\%$ and the lowest value of reducing sugars\%. This variation among genotypes may be due to the differences in their genetic make-up. Such data are in the same trend with Nour El Hoda et. al. (1994), Osman et. al. (2005) and Mohamed et. al. (2006).

Table 3. Effect of varieties on chemical composition .

\begin{tabular}{|c|c|c|c|c|c|c|}
\hline \multicolumn{7}{|c|}{2009 season } \\
\hline \multirow{3}{*}{$\begin{array}{c}\text { Sweet } \\
\text { sorghum } \\
\text { Varieties }\end{array}$} & \multicolumn{6}{|c|}{ Chemical composition } \\
\hline & \multicolumn{3}{|c|}{ Extracted juice } & \multicolumn{3}{|c|}{ Extracted syrup } \\
\hline & Sucrose\% & $\begin{array}{l}\text { Reducing } \\
\text { sugars\% }\end{array}$ & $\mathrm{pH}$ value & Sucrose $\%$ & $\begin{array}{l}\text { Reducing } \\
\text { sugars } \%\end{array}$ & $\begin{array}{c}\text { Syrup } \\
\text { extraction \% }\end{array}$ \\
\hline Honey & 10.90 & 2.35 & 3.83 & 28.27 & 30.78 & 5.13 \\
\hline Brandes & 11.76 & 2.17 & 3.73 & 29.80 & 29.84 & 8.83 \\
\hline Sorgo & 12.33 & 2.00 & 3.78 & 30.04 & 28.81 & 8.54 \\
\hline LSD $5 \%$ & 0.48 & 0.05 & NS & 0.65 & 0.75 & 2.02 \\
\hline \multicolumn{7}{|c|}{2010 season } \\
\hline Honey & 11.05 & 2.54 & 3.83 & 27.20 & 31.81 & 5.46 \\
\hline Brandes & 12.83 & 2.39 & 3.73 & 28.83 & 30.84 & 7.02 \\
\hline Sorgo & 13.44 & 2.17 & 3.78 & 29.02 & 29.83 & 9.11 \\
\hline LSD $5 \%$ & 0.32 & 0.10 & NS & 0.85 & 0.55 & 1.95 \\
\hline
\end{tabular}

\section{II: Potassium mineral fertilizer and biofertilization}

\section{- Yields and extracted juice}

The results in Table (4) showed a significant increase in yields of stripped stalks, juice and syrup/fed with potassium mineral fertilizer and biofertilization application at the rate of $30 \mathrm{~kg} \mathrm{~K}{ }_{2} \mathrm{O} / \mathrm{fed}+2$ bags Mag/fed followed by $36 \mathrm{~kg} \mathrm{~K} \mathrm{~K}_{2} \mathrm{O} / \mathrm{fed}$ without biofertilizer and $24 \mathrm{~kg} \mathrm{~K} 2 \mathrm{O} / \mathrm{fed}+2$ bags $\mathrm{Mag} / \mathrm{fed}$ in both seasons. This could 
be attributed to the positive effect of potassium on stalk weight, which showed low fiber content and high water content with the application of potassium. These results revealed the importance of mineral fertilizer and biofertilizers for increasing yield and juice extracted of plants.

Table 4. Effect of potassium mineral fertilizer and biofertilization on yield/fed and juice extracted \% .

\begin{tabular}{|c|c|c|c|c|c|c|}
\hline \multicolumn{7}{|c|}{2009 season } \\
\hline Potassium & \multicolumn{3}{|c|}{ Yields (ton/fed) } & \multicolumn{3}{|c|}{ Juice extracted } \\
\hline $\begin{array}{c}\text { (mineral and biofertilizer } \\
\text { Mag kg/fed.) }\end{array}$ & Stripped & Juice & Syrup & $\begin{array}{c}\text { Total soluble } \\
\text { solids \% }\end{array}$ & $\begin{array}{c}\text { Purity } \\
\%\end{array}$ & $\begin{array}{c}\text { Juice } \\
\text { extraction } \\
\%\end{array}$ \\
\hline $24 \mathrm{~K}_{2} \mathrm{O}+2$ bags $\mathrm{Mag} / \mathrm{fed}$ & 27.67 & 14.53 & 1.26 & 21.59 & 50.95 & 52.51 \\
\hline $30 \mathrm{~K}_{2} \mathrm{O}+2$ bags $\mathrm{Mag} / \mathrm{fed}$ & 29.81 & 16.20 & 2.93 & 18.15 & 71.74 & 54.34 \\
\hline $36 \mathrm{~K}_{2} \mathrm{O}$ & 28.50 & 15.03 & 2.48 & 20.78 & 62.37 & 52.74 \\
\hline LSD 5\% & 0.68 & 0.50 & 0.11 & 0.57 & 0.89 & 0.18 \\
\hline \multicolumn{7}{|c|}{2010 season } \\
\hline $24 \mathrm{~K}_{2} \mathrm{O}+2$ bags $\mathrm{Mag} / \mathrm{fed}$ & 28.67 & 13.10 & 1.35 & 21.76 & 56.02 & 45.69 \\
\hline $30 \mathrm{~K}_{2} \mathrm{O}+2$ bags $\mathrm{Mag} / \mathrm{fed}$ & 30.94 & 15.99 & 3.16 & 18.25 & 78.08 & 51.68 \\
\hline $36 \mathrm{~K}_{2} \mathrm{O}$ & 29.47 & 14.69 & 2.07 & 20.13 & 65.57 & 49.85 \\
\hline LSD $5 \%$ & 0.41 & 0.25 & 0.08 & 0.37 & 0.74 & 2.12 \\
\hline
\end{tabular}

\section{- Extracted juice}

Results in Table 4 show that treatment with $30 \mathrm{~kg} \mathrm{~K} / \mathrm{O} / \mathrm{fed}+2$ bags of $\mathrm{Mag} / \mathrm{fed}$ or $36 \mathrm{~kg} \mathrm{~K} \mathrm{~K}_{2} \mathrm{O} / \mathrm{fed}$ without biofertilizer had a significant increase in purity and juice extraction as compared with $24 \mathrm{~kg} \mathrm{~K} 2 \mathrm{O} / \mathrm{fed}+2$ bags Mag/fed in both seasons. The increase in purity\% might be due to the increase in sucrose $\%$ and decrease in non sugar substances\% of sorghum juice with potassium fertilization and syrup extraction \% (SEP) of sorghum syrup as compared with the control treatment. These results revealed the importance of potassium (mineral fertilizer twice) and biofertilization for physical properties of extracted juice. These results may be due to role of potassium (mineral fertilizer) in increasing photosynthesis activity and subsequently carbohydrate synthesis and its accumulation which is reflected on the TSS\%. Role of potassium biofertilizer may be due to increasing available nutrients for growth and subsequently juice quality. These results are in agreement with those reported by El-Zeny (2004), Mohamed et. al. (2006) and Moustafa et. al. (2006). 


\section{- Chemical composition}

Results in Table (5) showed a significant increase in chemical composition with potassium (mineral fertilizer) and biofertilization. Potassium (mineral fertilizer) and biofertilizer application at $30 \mathrm{~kg} \mathrm{~K}{ }_{2} \mathrm{O} / \mathrm{fed}+2$ bags Mag/fed significantly increased sucrose $\%$ in the extracted juice and syrup than other treatments in both seasons. However, the same treatment gave the lowest reducing sugars\%. There are a variety of reasons to explain the effect of potassium application on sucrose content, one of them may be due to improving the functional quality of sugar beet which could be seen in stimulation of assimilation and translocation of sugar from leaves to the beet. Potassium also prepares osmotically the beet cells to store large amounts of sugars (Krauss, 2000).

Table 5. Effect of potassium mineral fertilizer and biofertilization on chemical composition.

\begin{tabular}{|c|c|c|c|c|c|c|}
\hline \multirow{2}{*}{ Potassium } & \multicolumn{5}{|c|}{2009 season } \\
\cline { 2 - 7 } & \multicolumn{5}{|c|}{ Juice extracted } & Syrup extracted \\
\hline $\begin{array}{c}\text { (mineral and biofertilizer } \\
\text { Mag kg/fed.) }\end{array}$ & Sucrose\% & $\begin{array}{c}\text { Reducing } \\
\text { sugar\% }\end{array}$ & $\begin{array}{c}\mathrm{pH} \\
\text { value }\end{array}$ & $\begin{array}{c}\text { Sucrose } \\
\%\end{array}$ & $\begin{array}{c}\text { Reducing } \\
\text { sugar\% }\end{array}$ & $\begin{array}{c}\text { Syrup } \\
\text { extraction } \\
\%\end{array}$ \\
\hline $24 \mathrm{~K}_{2} \mathrm{O}+2$ bags Mag/fed & 11.00 & 3.26 & 4.65 & 28.24 & 29.63 & 4.55 \\
\hline $30 \mathrm{~K}_{2} \mathrm{O}+2$ bags Mag/fed & 13.02 & 1.99 & 4.85 & 30.40 & 27.25 & 9.83 \\
\hline $36 \mathrm{~K} \mathrm{O}$ & 12.96 & 2.98 & 4.85 & 29.48 & 28.56 & 8.70 \\
\hline LSD 5\% & 0.39 & 0.13 & $\mathrm{NS}$ & 0.61 & 0.31 & 3.49 \\
\hline $24 \mathrm{~K}_{2} \mathrm{O}+2$ bags Mag/fed & 12.19 & 3.31 & 4.65 & 29.27 & 30.91 & 4.71 \\
\hline $30 \mathrm{~K}_{2} \mathrm{O}+2$ bags Mag/fed & 14.25 & 1.02 & 4.85 & 31.27 & 28.23 & 10.21 \\
\hline $36 \mathrm{~K} 2 \mathrm{O}$ & 13.20 & 2.03 & 4.85 & 30.51 & 29.34 & 7.02 \\
\hline LSD 5\% & 0.31 & 0.12 & $\mathrm{NS}$ & 0.55 & 0.65 & 4.77 \\
\hline
\end{tabular}

\section{REFERENCES}

1. A. O. A. C. 2005. Association of Official Analytical Chemists. Official Methods of analysis, $26^{\text {th }}$ Ed., A.O.A.C. International, Washington, D.C., USA.

2. Aly, M. H., Amal M. Kamel and Samia Hassan. 2008. The usage of biofertilizer to minimize the mineral fertilizer for sweet sorghum. Egypt.J. Appl. Sci., 23 (2B): 486-499.

3. CCSC. 2010. Sugar Crops Council. Annual Report, Ministry of Agriculture, Egypt. (In Arabic). 
4. Chawdhury, M.K. and M.H. Rahman. 1990. Potash requirement of sugarcane in Gangetic River Flood Plain Soil of Bangladesh. J. Ind. Soc., of Soil. Sci., 38 (4): 688-691.

5. Collins, J. L., C. B. Ebah, I.M. Mc Carty and J.R. Mount. 1987. Clarification of sorghum juice for syrup by using Bentonite and Heat. Tennessee Form and Home Sci., Spring, (142): 16-20. (C.A. Shady, K.A. Ph.D. Thesis, Fac. Agric., Zagazig Univ. (1998).

6. El-Zeny, Maha M. 2004. Response of sweet sorghum to appropriate fertilizer regimes. Ph.D. Thesis, Fac. Agric., Moshtohor, (Benha branch), Zagazig Univ. Egypt.

7. Ismail, A.M.A., S.A. Mohamed, Samia Y. Mohamed and Nahed O. Zohdy. 2007. Response of sorghum to mineral and bio nitrogen. Egypt. J. Agric. Res. 85 (2): 573-586.

8. Jakson, M. L. 1967. Soil Chemical Analysis. Prentice Hall. Inc. Englewood Cliffs NJ USA.

9. Krauss, A. 2000. Role of potassium in the system of sugar beet fertilization. International Potash Institute IPI Optimizing Crop Nutrition.

10. Miller, R. W. and S. D. Creelman. 1982. Sorghum a new fuel. $35^{\text {th }}$ Annals. Corn and Sorghum Res. Conf. pp 219-232.

11. Mohamed, K.E., H. Ferweez and S.M. Allam. 2006. Effect of $K$ fertilization on yield and quality of sweet sorghum juice and syrup. Bull. Fac. Agric. Cairo Univ. 57: 401-416.

12. Moustafa, Zeinab, R., H. W. A. Wahba and H. A. Samia. 2006. Effect of injected ammonia Gas and applied potassium rates with or without some microniutrients on sugar beet productivity. Annals agric. Sci., Moshtohor, 44 (4): 1447-1460.

13. Nour El Hoda, M., F.A. El-Latie, M.S. Mona and M.S. Laila. 1994. Yield and quality of juice and syrup of sweet sorghum with relation to sowing dates and harvest stages. J. Agric. Sci. Mansoura Univ. 24 (6): 2701-2709.

14. Osman, M. S. H., H. Ferweez and A. M. H. Osman. 2005. Productivity and technological qualities of juice and syrup of nine sweet sorghum (Sorghum bicolor L. Moench) varieties. Egyptian J. of Agric. Res. 83: (3): pp 1255-1267.

15. Snedecor, G. W. and W. G. Cochran. 1981. Statistical methods $6^{\text {th }}$ Ed. Iowa State Univ. Press. Ames. Iowa. USA.

16. Undersander, D. J., W. E. Lueschen, L. H. Smith, A. R. Kaminski, J. Doll, K. Kelling and E. S. Oplinger. 1990. Sorghum for syrup. Co. Ext. Ser., Univ. WI. 53706, pp. $1-13$. 
استجابة ثلاثة اصناف من الأرة الرفيعة السكرية للتسميد البوتاسى المعدنى والحيوى صلاح رفاعى امام الثيخ اثرف حنفى سيد احمد اللبودى عادل محمود حسن عثمان

$$
\text { معهز بحوث المحاصيل السكرية - مركز البحوث الزراعية - مصر }
$$

اقيمت تجربتين حقليتين بجركز البحوث الزراعية (محطة بحوث الجيزة) فى صيف 2009

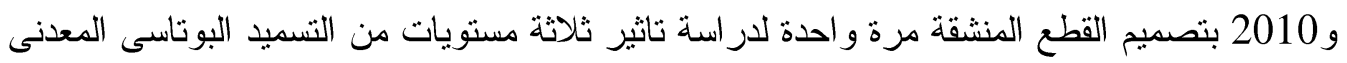

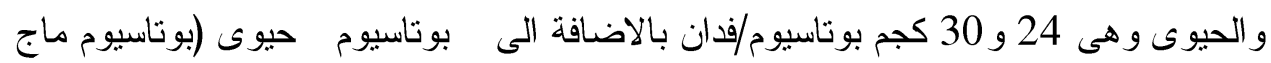

2كيس/فدان) الموصى به و36 كجم بوتاسيوم معدنى بدون تسميد حيوى على محصول العيدان

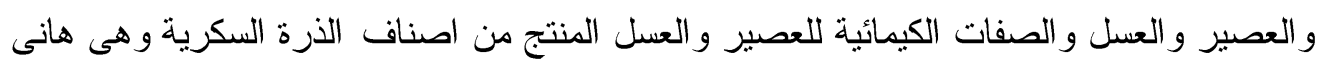
وبر اندز وسورجو.

\section{كاتت النتائج كالاتى:}

1. اختلفت الاصناف معنويا فى الصفات المحصولية وهى محصول العيدان النظيفة

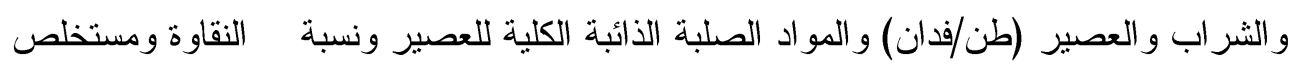
العصير و ايضا المركبات الكيميائية مثل النسبة المئوية للسكروز و السكريات المختزلة فى العصبير و الثراب وقد تفوق الصنف سورجو ثم الصنف بر اندز ثم الصنف هانى فى كلا الموسميين.

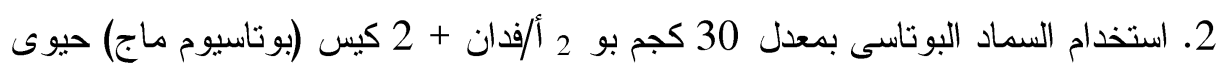

بوتاسيوم الى زيادة معنوية فى معظم الصفات السالفة الذكر . 3. لم يكن للتداخل بين الاصناف و التسميد البوتاسى المعدنى و الحيوى تاثير معنوى على اى

$$
\text { من الصفات السابقة فى كلا الموسميين. }
$$

يوصى هذا البحث بأنه لزيادة المحصول وتحسين معظم خو اص العصير و الثراب الناتج

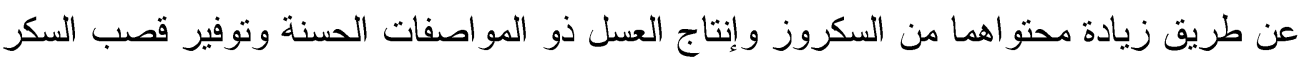

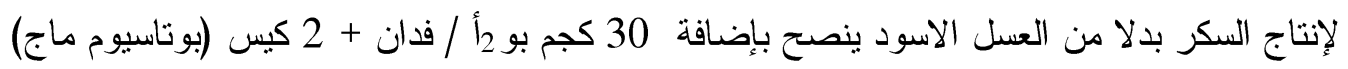

حيوى بوتاسيوم واستخدام صنف الذرة الرفيعة السكرية سورجو ثم براندز ثم الصنف هانى على لإنى التو الىى. 